\title{
The lymphoproliferative auto-immune syndrome: a rare cause of peripheral cytopenia
}

\author{
Raida Ben Salah¹, Mona Snoussi', Nour Louati², Chebbi Donia', Faten Frikha', Mnif Hela², Bahloul Zouhir ${ }^{1}$
}

\begin{abstract}
Autoimmune Lymphoproliferative syndrome is an inherited disorder manifesting with autoimmune cytopenia, lymphadenopathy and splenomegaly. The differential diagnosis includes infections, autoimmune disorders or malignancies. The disease is characterized by accumulation of double negative (CD3+ CD4- CD8-) T cells (DNT) in the peripheral blood. Here we report the case of 19 years-old girl that was diagnosed as autoimmune Lymphoproliferative syndrome with a literature review.
\end{abstract}

Keywords: lymphoproliferative auto-immune syndrome, cytopenia

\section{INTRODUCTION}

Autoimmune lymphoproliferative syndrome (ALPS) is a rare inherited disorder occurring in childhood characterized by splenomegaly, massive lymphadenopathy, immune cytopenia and accumulation of double-negative (CD3+CD4-CD8) T cells in the blood $(1,2)$. Here we report the case of 19 years-old girl that was diagnosed as ALPS with a literature review.

\section{CASE REPORT}

The patient was referred to the department of internal medicine in October 2011 at the age of 16 with severe anemia and systemic lupus suspicion. She was the first child of non-consanguineous marriage, her brother died at the age of 9 with a severe thrombocytopenia and her sister aged of 8 was hospitalized many times in pediatric department with hemolytic anemia. At the age of 11 , the patient was first admitted to the pediatric department with diffuse petechiae, purpura and epistaxis of one week's duration. On examination, there were extensive purpuric lesions over the upper neck and extremities and the spleen was palpable $2-3 \mathrm{~cm}$ below costal margin. Initial complete blood count showed severe thrombocytopenia. The platelet count was $30000 \mathrm{elts} / \mathrm{mm} 3$. A bone marrow aspiration was performed and revealed no abnormalities. Viral serologic studies including CMV, EBV, HSV, Rubella, HBV, HCV, HIV and Toxoplasma were negative. The diagnosis of autoimmune thrombocytopenia was made and the patient was treated with high dose of corticosteroids (prednisolone $1 \mathrm{mg} / \mathrm{Kg} /$ day) was started with favorable outcome. Later, she has presented the relapses of thrombocytopenia requiring high dose of corticosteroids each time. In January 2011, a splenectomy was performed because of severe relapsing thrombocytopenia with a normalization of platelets counts. In October 2011, she was hospitalized for icterus and fever. Her blood count revealed a hemoglobin level of $4 \mathrm{~g} / \mathrm{dl}$, an hematocrit of $29 \%$, white blood cell count of 30.6D109/I, lymphocyte of $11.3109 / \mathrm{I}$, and platelet count of 3.0D $109 / \mathrm{I}$. The reticulocyte count was $1 \%$. The direct Coomb's test was positive to $\mathrm{lg} \mathrm{G}$. The diagnosis of auto immune hemolytic anemia was made and the patient was treated with High-dose of corticosteroids with normalization of hemoglobin level. Virological and bacteriological tests were negative. Nevertheless, immunological tests showed a positive antinuclear antibody with a titer of 1/1280. She was transferred to our department for suspicion of systemic lupus. At her admission, her physical examination was normal and then the diagnosis of systemic lupus was ruled out. To investigate the lymphocytosis a whole body tomography showed multiple mediastinal and retroperitoneal and para-aortic lymph nodes and a bone marrow

\footnotetext{
1 Department of Internal Medicine, Hedi Chaker Hospital Sfax, Tunisia

Correspondence: Raida Ben Salah

2 Center of Transfusion, Hedi Chaker Hospital Sfax, Tunisia

Department of internal medicine, Hedi Chaker Hospital Sfax, Tunisia.

Received: 11 Jun 2018, Accepted: 8 Aug 2018

E-mail: raidabensalah@yahoo.fr
}

(C) 2018 by the authors; licensee Modestum Ltd., UK. This article is an open access article distributed under the terms and conditions of the Creative Commons Attribution License (http://creativecommons.org/licenses/by/4.0/). 
aspiration revealed an infiltrate consisting of transforming lymphocytes of $35 \%$. Flowcytometry of peripheral blood reported increased numbers of CD4-CD8- T cells (\%).According to the previous findings, the diagnosis of APLS was retained. In April 2017, the patient experienced a severe hemolytic anemia, hemoglobin failed to increase with systemic steroids leading quickly to her death because of multivisceral organ failure and heart attack.

\section{DISCUSSION}

Autoimmune lymphoproliferative syndrome (ALPS), was first described by Canale-Smith in 1967. It is a rare disease observed mainly in childhood (3). The main symptoms of this entity are lymphadenopathy, hepatosplenomegaly, autoimmune disorders and sometimes fatal complications such as Hodgkin's and Non-Hodgkin's lymphoma $(4,5)$. APLS is due to heritable mutation in FAS ligand gene programmed death or apoptosis of lymphocytes (6). Autosomal dominant FAS mutation with variable penetrance and expressivity is identified in the majority of APLS cases $(7,8)$. The lack of Fas Ligand expression on lymphocytes leads to defect in apoptosis and then to chronic nonmalignant lymphoproliferation and the accumulation of double-negative (CD3+CD4-CD8-) T cells in the blood and autoimmune manifestations $(1,9,10)$. Most of the autoimmune disorders associated with ALPS target and damage blood cells. Comparatively to our patient, cytopenias are usually chronic and refractory and most severe in early childhood. ALPS-related autoimmunity sometimes targets other organs, leading to conditions such as uveitis, hepatitis, glomerulonephritis, infiltrative pulmonary lesions, and encephalitis and myelitis (manifesting as aseptic meningitis and even or the connective tissues like systemic lupus erythematosus which make the diagnosis more difficult (11). In the present case, there were not a sufficient data to meet the criteria of systemic lupus. So, we insist on the possibility of positivity of antinuclear antibody without organic damages. In fact, in APLS multiple autoantibodies, frequently those against red blood cells presenting as a positive Coomb direct antiglobulin test, have been demonstrated, even in the absence of overt autoimmune diseases (12). The diagnosis of ALPS is currently based on criateria established by the First International ALPS Workshop in 2009 requiring the presence of chronic lymphadenopathy and/or splenomegaly and elevated circulating TCR $\alpha \beta^{+} C D 4^{-} C D 8^{-} D N T$ cells (13). Characteristic histopathologic findings lymph node are also helpful for diagnosis of ALPS-FAS. These include paracortical expansion with infiltration by polyclonal TCR $\alpha \beta^{+}$DNT cells accompanied by follicular hyperplasia and polyclonal plasmacytosis (14). In our patient, the family history of autoimmune cytopenia in childhood and the peripheral nonmalignant lymph proliferation were helpful for the diagnosis. Unfortunately, we were unable to evaluate the defect of lymphocyte apoptosis in vitro or detect the affected gene due to lack of these test in our hospital. The risk of transformation lymphoma should be considered in APLS particularly in patient with mutations abrogating function of the intracellular domain of the FAS protein. In fact, the risk of an ALPS patient developing Hodgkin lymphoma is estimated at 50 times that of the general population, and the risk of NHL is increased 14-fold in them (15). The management of ALPS is usually difficult. The recurrent flares of auto-immune cytopenia need a corticosteroid therapy with intravenous methylprednisolone pulses followed oral prednisone $(1-2 \mathrm{mg} / \mathrm{kg})$ as a maintenance therapy that can often be successfully tapered over several weeks. Intravenous immunoglobulin is associated to corticostoids in case of severe AlHA. In situation of refractory, chronic cytopenias, MMF and then rituximab constitute the alternative therapy and finally the practice of splenectomy. Allogeneic hematopoietic stem cell transplantation was also successful in selected ALPS patients with lymphoma or refractory cytopenia (16). Patients require a long-term monitoring with periodic CT and DFG PET scan for screening lymphoma. In our case, the auto immune disorders were serious and rapidly fatal so that were unable to associate other immunosuppressant therapy.

\section{CONCLUSION}

ALPS should always be considered in the diagnosis of recurrent and refractory peripheral auto immune cytopenia especially when it is revealed in early age. Our case report was also particular by the delay of lymphoproliferative infiltration declared in adulthood. Through the present case we would like to emphasize on the importance of earlier diagnosis and treatment initiation of this disease.

\section{REFERENCES}

1. Clementi R, Dagna L, Dianzani U, Dupre L, Dianzani I, Ponzoni M, et al. Inherited perforin and Fas Mutations in a patient with Autoimmune Lymphoproliferative Syndrome and Lymphoma. N Engl J Med. 2004;351(14):1419-24. https://doi.org/10.1056/NEJMoa041432 PMid:15459303 
2. Aspinall Al, Pinto A, Auer IA, Bridges P, Luider J, Dimnik L, et al. Identification of New Fas Mutations in a patient with Autoimmune Lymphoproliferative Syndrome (ALPS) and Eosinophilia. Blood cells Mol Dis. 1999;25(3-4):22738. https://doi.org/10.1006/bcmd.1999.0248 PMid:10575548

3. Canale VC, Smith CH. Chronic lymphadenopathysimulating malignant lymphoma. J Pediatr. 1967;70:891-9. https://doi.org/10.1016/S0022-3476(67)80262-2

4. Malzberg MS, Haller JO, Snieckus PJ, Halpern SL. Canale-Smith syndrome: chronic pseudomalignant lymphadenopathy. J Clin Ultrasound. 1991;19:172-4. https://doi.org/10.1002/jcu.1870190309 PMID: 1849925

5. Sneller MC, Wang J, Dale JK, Strober W, Middelton LA, Choi Y, Fleisher TA, Lim MS, Jaffe ES, Puck JM, Leonardo MJ, Straus SE. Clinical, immunologic, and genetic features of an autoimmune lymphoproliferative syndrome associated with abnormal lymphocyte apoptosis. Blood. 1997;89:1341-8. PMid:9028957

6. Gren H, GHlen H, Duman M, UJar C, Atabay B, Yılmaz S, I'rken G. Autoimmune lymphoproliferative syndrome: report of two cases and review of the literature. Ann Hematol. 2002;81:651-3. https://doi.org/10.1007/s00277002-0537-5 PMid:12454704

7. Holzelova E, Vonarbourg C, Stolzenberg MC, Arkwright PD, Selz F, Prieur AM, Blanche S, Bartunkova J, Vilmer E, Fischer A, Le Deist F, Rieux-Laucat F. Autoimmune lymphoproliferative syndrome with somatic Fas mutations. $N$ Engl J Med. 2004 Sep 30;351(14):1409-18. https://doi.org/10.1056/NEJMoa040036 PMid:15459302

8. Magerus-Chatinet A, Neven B, Stolzenberg MC, Daussy C, Arkwright PD, Lanzarotti N, Schaffner C, CluetDennetiere S, Haerynck F, Michel G, Bole-Feysot C, Zarhrate M, Radford-Weiss I, Romana SP, Picard C, Fischer A, Rieux-Laucat FJ. Onset of autoimmune lymphoproliferative syndrome (ALPS) in humans as a consequence of genetic defect accumulation. Clin Invest. 2011 Jan;121(1):106-12. https://doi.org/10.1172/JCl43752

9. Aspinall Al, Pinto A, Auer IA, Bridges P, Luider J, Dimnik L, et al. Identification of New Fas Mutations in a patient with Autoimmune Lymphoproliferative Syndrome (ALPS) and Eosinophilia. Blood cells Mol Dis 1999;25(3-4):22738. https://doi.org/10.1006/bcmd.1999.0248 PMid:10575548

10. Fisher G, Rosenberg F, Straus S, Dale J, Middelton L, Lin A,Strober W, Lenardo M, Puck J. Dominant interfering fas gene mutation impair apoptosis in a human autoimmune lymphoproliferative syndrome. Cell. 1995;81:93546. https://doi.org/10.1016/0092-8674(95)90013-6

11. Koneti Rao V, Oliveira JB. How I treat autoimmune lymphoproliferative syndrome. Blood. 2011 Nov 24;118(22):5741-51. https://doi.org/10.1182/blood-2011-07-325217 PMid:21885601 PMCid:PMC3228494

12. Stroncek DF, Carter LB, Procter JL, Dale JK, Straus SE. RBC autoantibodies in autoimmune lymphoproliferative syndrome. Transfusion. $2001 \quad$ Jan;41(1):18-23. https://doi.org/10.1046/j.1537-2995.2001.41010018.x PMid: 11161240

13. Oliveira JB, Bleesing JJ, Dianzani U, Fleisher TA, Jaffe ES, Lenardo MJ, Rieux-Laucat F, Siegel RM, Su HC, Teachey DT, Rao VK. Revised diagnostic criteria and classification for the autoimmune lymphoproliferative syndrome (ALPS): report from the $2009 \mathrm{NIH}$ International Workshop. Blood. 2010 Oct 7;116(14):e35-40. https://doi.org/10.1182/blood-2010-04-280347 PMid:20538792 PMCid:PMC2953894

14. Koneti Rao V, Oliveira JB. How I treat autoimmune lymphoproliferative syndrome. Blood. 2011 Nov 24;118(22):5741-51. https://doi.org/10.1182/blood-2011-07-325217 PMid:21885601 PMCid:PMC3228494

15. Straus SE, Jaffe ES, Puck JM, Dale JK, Elkon KB, Rösen-Wolff A, Peters AM, Sneller MC, Hallahan CW, Wang J, Fischer RE, Jackson CE, Lin AY, Bäumler C, Siegert E, Marx A, Vaishnaw AK, Grodzicky T, Fleisher TA, Lenardo MJ The development of lymphomas in families with autoimmune lymphoproliferative syndrome with germline Fas mutations and defective lymphocyte apoptosis. Blood. 2001 Jul 1;98(1):194-200. https://doi.org/10.1182/blood.V98.1.194 PMid:11418480

16. Benkerrou M, Le Deist F, de Villartay JP, Caillat-Zucman S, Rieux-Laucat F, Jabado N, Cavazzana-Calvo M, Fischer A. Correction of Fas (CD95) deficiency by haploidentical bone marrow transplantation. Eur J Immunol. 1997 Aug;27(8):2043-7. https://doi.org/10.1002/eji.1830270831 PMid:9295043

$\diamond \diamond \diamond \diamond \diamond \diamond \diamond$

http://www.ejgm.co.uk 